
studenata medicine i liječnika

\title{
Štamparovi pogledi na zdravstvenu edukaciju učenika u školama, studenata medicine i liječnika
}

\author{
Marica Jandrić-Balen \\ Slavonski Brod \\ marica@jandric.com \\ Ivica Balen \\ Slavonski Brod \\ ivekbalen@gmail.com
}

SAŽETAK: Prosvjetiteljstvo i pučka prosvjeta bili su Štamparova opsesija od mladosti. Uz to, uvijek je pokazivao i veliko zanimanje za zdravstveni odgoj u školama, ali i za nastavu na medicinskim fakultetima te za trajnu edukaciju diplomiranih liječnika. Prvi je put predložen za fakultetskoga nastavnika već 1922. godine, ali je tek osnivanjem Banovine Hrvatske dobio dozvolu za rad na Medicinskom fakultetu u Zagrebu. Tada je već imao 51 godinu. Vrlo brzo, već 1940. postao je dekan Medicinskoga fakulteta u Zagrebu, ali je nažalost tu karijeru prekinuo Drugi svjetski rat. Tijekom rata bio je interniran u Austriji, a nakon rata nastavio je raditi kao fakultetski nastavnik i ravnatelj Škole narodnoga zdravlja, koju je od 1947. godine uključio u fakultetsku dodiplomsku i postdiplomsku nastavu. Od 1952. godine pa do kraja života u ljeto 1958. godine pet puta za redom biran je za dekana Medicinskoga fakulteta u Zagrebu. Osnivač je drugoga medicinskoga fakulteta u Hrvatskoj, onoga u Rijeci 1956. godine. U okviru Medicinskog fakulteta u Zagrebu sredinom pedesetih godina XX. st. otvara Višu školu za medicinske sestre. Uvodi i dvogodišnju školu za bolničare, nakon završenoga osnovnog školovanja. Iako se fakultetskom nastavom bavio samo 15 godina, uglavnom pred kraj života, ipak je pridonio i tom području, prije svega stalnim nastojanjima u afirmaciji preventivne medicine, higijene i socijalne medicine.

Ključne riječi: Andrija Štampar, zdravstvena edukacija, Medicinski fakultet

\section{Štampar i srednjoškolski zdravstveni odgoj}

Kao mladi student i mladi liječnik, Štampar je najviše razmišljao o zdravstvenom odgoju u srednjim školama, što je razumljivo jer još nije imao iskustava s fakultetskom nastavom, osim s pozicije studenta u Beču. $U$ to doba uglavnom razmišlja o edukaciji učenika u srednjim školama i ima primjedbe s kojima misli da bi se trebao unaprijediti zdravstveni odgoj. Tako u Zvonu 1909. godine piše o svojoj najvažnijoj temi - borbi protiv alkohola i alkoholizma: »U našim čitankama za niže i srednje 
škole nema niti jednog štiva, koje bi obrađivalo alkoholno pitanje /.../ U najnovije doba dobili su srednjoškolci knjigu „Nauka o zdravlju“, u kojoj je u vrlo kratkim crtama prikazan alkoholizam. U njoj se govori jedino protiv pijanstva, a o apstinenciji nema ni govora, dapače dozvoljava se žestoka pića iznad 15 godina. Svatko može sebi da pomisli, kako će ovo razumjeti jedan srednjoškolac. O mjerama uživanja žestokih pića ne može biti govora, jer slabo mladi ljudi znaju koliko im škodi. Prema tome u higijeni se može preporučiti samo apstinencija . $^{1}$
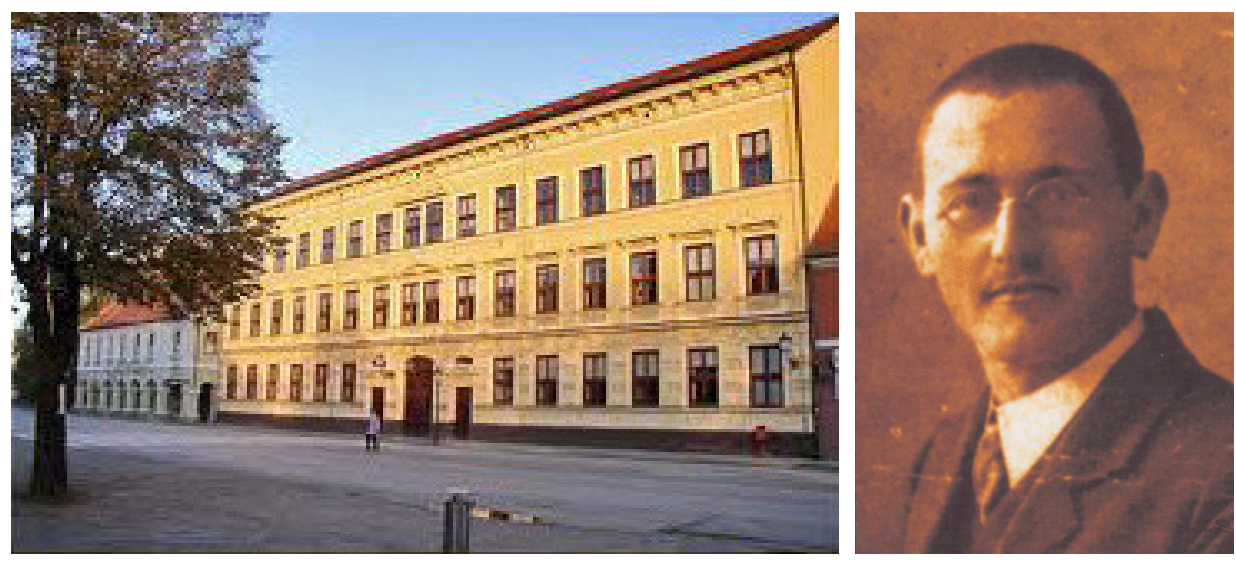

Slika 1. Gimnazija u Vinkovcima u kojoj je Štampar proveo osam godina Slika 2. Štampar kao student medicine u Beču

Već u mladosti, uz izraženo domoljublje, imao je Štampar i širok globalni pogled na svijet oko sebe, stalno propitujući kako što rade drugi narodi i nastojeći se ugledati u one koji su napredniji od nas. Hvali napore drugih zemalja na suzbijanju alkoholizma, osobito Njemačku, Švicarsku, Norvešku, Švedsku i Finsku. Hvali finski zakon iz 1907. godine kojim je država zabranila uvoz i prodaju žestokih pića. Uvjeren je kako je to jedini put da »čovječanstvo ne trpi pod jarmom alkoholizma«. Iste godine u još jednom broju Zvona raspravlja o dosta raširenom mišljenju kako je apstinencija od alkohola čista utopija. Nada se i vjeruje kako će se u budućnosti odgojem stvoriti nova kultura u kojoj će se stvarati generacije potpunih apstinenata. ${ }^{2}$

1 Grmek, M. D. »Životni put Andrije Štampara, borca za unapređenje narodnog zdravlja«. U: Izabrani članci Andrije Štampara. Izdavački zavod Jugoslavenske akademije, Zagreb 1965., str. 13-49; Vukovac, S. »Hercules 20. stoljeća«. U: M. Bitunjac, T. Vlainić (ur.), Andrija Štampar, članci i rasprave, II. Sveučilište J. J. Strossmayera u Osijeku, sveučilišni udžbenik. Privlačica, Vinkovci 2008., str. 9-44; Balen, I., Jandrić-Balen, M. »Štampar kao prosvjetitelj«. U: I. Balen, L. Kovačić (ur.), Andrija Štampar, Radovi sa znanstvenih skupova Dani Andrije Stampara u Slavonskom Brodu. Posavska Hrvatska, Slavonski Brod 2009., str. 9-21.

2 Štampar, A. »Iz područja socijalne medicine: Rad oko dizanja narodnog zdravlja«. Zvono, 3(1909) 24, str. 645-650. 
U istom se članku žali na nedostatak spolnoga odgoja u školi, ali i kod kuće u obitelji: »Sada kada je izdana obligatna „Nauka o zdravlju“, te će se prema njoj odsele morati ravnati svaki učitelj higijene, baš u toj knjizi nema ni spomena o spolnim bolestima. A to je najveća mana«. Smatra da je nedostatak spolnoga odgoja glavni uzrok širenja spolnih bolesti i brojnih tragedija koje neukost o tim bolestima izaziva u društvu. Stoga se jako zalaže za seksualno prosvjećivanje mladih, iako je svjestan da je to u konzervativnoj sredini vrlo teško postići. Kao mladi liječnik 1919. zalaže se za seksualni odgoj i zbog toga što tada već postoji svijest o dječjoj seksualnosti, zahvaljujući radu velikoga psihoanalitičara i bečkoga profesora Sigmunda Freuda. ${ }^{3}$ Svjestan je širine društvenih mjera kojima treba suzbijati bolest, ali i dalje smatra da je edukacija učitelja i učenika važan korak u unapređenju zdravlja. Zalagao se za seksualni odgoj koji treba početi u višim razredima srednjih škola.

njĭ čovjek oboli, jer uvijek je bolje uraniti nego zakasnıtı.

Zabrinuti roditelji i odgojitelji staroga kova zgražaju se već kod pomisli, da se djeci o tome govori, a kamoli, da se to doista i provodi. Većina krivo misli, da su djeca posve nevina i da o spolnom odnošaju nemaju ni pojma.

Marija Lišnevska u svojaj izvrsnoj studiji o tom pitanju donosi mnogo primjera, kako djeca u najranijoj dobi znaju za takove stvari, o kojima mi ni u smu ne sanjamo. Klasičan je ovaj primjer: Perica, dijete od sedam godina, zapita svoju majku: "Kaži mi, mama, odakle dolaze djeca?" - "Kupuju se." - "Ja mislim, da se ne kupuju!" - "Zašto?" - "Jer ih siromasi najviše imaju."

Dr. Antić (po knjizi prof. Jovanović-Batuta: Seljačka kuća) spominje upravo drastičan primjer. Muž i žena poslije izvjesnog vremena, kad su polijegali zajedno s djecom, htjedoše de vrše seksualan akt. Žena će reći mužu, da čekne, dok djeca pospu. Poslije nekog vremena javi se njihova djevojčica od 12-14 god.: "Tata, sad možeš, jer djeca spavaju."

Slika 3. U fugoslavenskoj njivi 1919., zalažući se za seksualni odgoj, navodi i dvije šale na temu dječjega odnosa prema seksualnosti

Dajući primjedbe na novi Zakon o čuvanju zdravlja, osobito na njegov preventivni dio, u Liječničkom vjesniku 1919. godine piše: »U svim školama uvađa se zdravstvena pouka, koju će propisati ministar za zdravlje u sporazumu s ministrom za prosvjetu /.../ U više razrede srednjih škola uvodi se seksualno spolno poučavanje /.../ U učiteljskim školama, na sveučilištu, u bogoslovijama uređuju se posebni tečajevi za školsku higijenu, koje će pohađati učiteljski kandidati, a na sveučilištu ona lica, koja će se posvetiti učiteljskom zvanju /.../«. Njemu je jasno da se mora uskladiti doktrina, kako bi svi u društvu, od ministara preko svih nastavnika do liječnika, imali iste stavove

3 Štampar, A. »Iz područja socijalne medicine: Školski liječnik«. Zvono, 3(1909) 26, str. 710-713 
(predlaže iste tečajeve i za praktične liječnike) i takav zdravstveni odgoj sustavno i uporno treba provoditi u školama. ${ }^{4}$

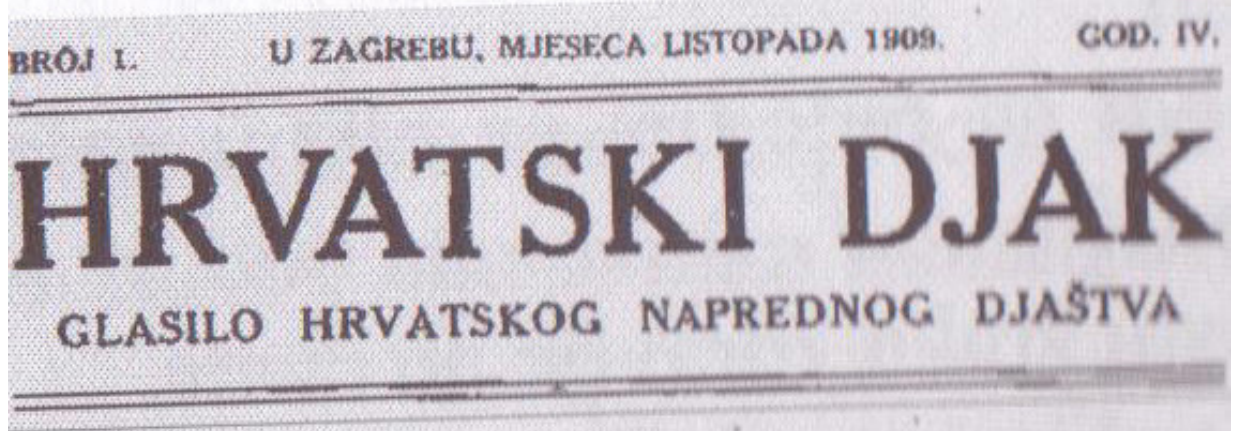

Slika 4. U svibnju 1909. Štampar u Hrvatskom djaku raspravlja o »Idealima života«

Kao student bio je vrlo kritičan prema cijelom školskom sustavu u Hrvatskoj u okvirima Austro-Ugarske Monarhije i to je svoje razmišljanje objavio u zagrebačkom listu Hrvatski djak 1909. godine: »Naš školski sistem odgaja u našim mladim ljudima najviše činovnike, ljude uskih grudi (mi bi danas rekli uskogrudne), slabog poleta, malenog znanja. Nije taj školski sistem zavladao samo kod nas, već se na njega tuže i drugdje, gdje su napredne misli uhvatile malo više korijena, nego kod nas«. U istom članku ističe kako je važno da mladi ljudi imaju ideal za koji se vrijedi boriti cijeli život jer ako toga ideala nema u životu brzo posustajemo i odlazimo na stranputicu. ${ }^{5}$

Štampar smatra kako je odsustvo ideala odgovornost i školskoga sustava i ne razmišlja o kućnom obiteljskom odgoju kao mogućem uzroku gubitka motivacije i ideala, a sve je to povezano is njegovim organicističkim (kolektivističkim) pogledom na društvo u cjelini. Tako 1919. godine u Glasniku Ministarstva narodnoga zdravlja piše: »Organicistička škola zastupajući stanovište, da se društvo mora promatrati kao organizam, djeluje snažno i na razvitak medicinske nauke. Kao što se pojedini organizam sastoji od ćelija, tako u društvu pojedinci reprezentiraju ćelije; kao što pojedini organizam boluje, tako može bolovati i društvo /.../ Objekt medicinskog promatranja je društveni, a ne individualni organizam, a liječnik kao zastupnik medicinske nauke počinje pipati bilo društva/.../«. Grubo rečeno, za Štampara i organiciste pojedinac je stanica, a tkivo, organi i cijeli organizam su nacije, države i cijelo čovječanstvo. U skladu s tim, on vjeruje snažno u društvenu intervenciju i promjene na razini društva koje mogu unaprijediti zdravlje, dok smatra gotovo beznačajnim liječiti

4 Štampar, A.»Seksualna pedagogika kao sredstvo u borbi protiv spolnih bolesti«. Fugoslavenska njiva, 3(1929) 14, str. 222-227.

5 Štampar, A. »Primjedbe k osnovu zakona o čuvanju narodnog zdravlja. Preventivni dio zakona«. Liječnički vjesnik, 41(1919) 8, str. 424-429; Isti, »Ideali života«, Hrvatski djak, 4(1909) 1, str. $10-11$. 
pojedinu stanicu jer time u društvu ne možemo postići mnogo. Razvija i podupire svijest o liječenju bolesti općim društvenim mjerama - socijalnom terapijom. Unaprjeđenje uvjeta stanovanja (grijanje, prozračnost, svjetlo), zaštita dojenčadi i male djece od najčešćih bolesti, opće zdravstveno osiguranje, dispanzeri za tuberkulozu i spolne bolesti te zaštita školske djece samo su neke od mjera koje smatra važnima za unaprjeđenje zdravlja. ${ }^{6}$

\section{Štamparova razmišljanja o studiju medicine}

Prvi put o nastavi na medicinskim fakultetima Štampar progovara s pozicije načelnika za higijenu u Ministarstvu narodnoga zdravlja. U Glasniku Ministarstva, u kojem je bio i urednik, 1920. godine izlaže svoje ideje kako popraviti edukaciju studenata medicine da budu bolji liječnici. Žali se na lošu pripremu studenata medicine kroz srednju školu pa piše: »Pored bezbroj sati o mrtvim i živim jezicima, gramatici, sintaksi, što sve zajedno nije uspjelo da i jednog đaka nauči pošteno ma kojem jeziku, ostavlja se upravo neznatan broj sati za obuku prirodnih nauka, a higijeni se smilovaše i ostaviše je za šesti razred /.../ Moja su iskustva u tome upravo porazna i gorka. Ispitivao sam svoje sudrugove o najosnovnijim pojavama prirode i u devedeset i devet postotaka nailazio sam na potpuno neznanje, kojemu je bila kriva samo naša formalistička škola.« Za njega očito nije problem u nedovoljnom učenju latinskog, jer smatra da se i taj jezik uči sasvim dovoljno i za potrebe medicinskoga studija, već je problem u nedovoljnoj edukaciji svih prirodnih predmeta, što se kasnije na fakultetu teško može nadoknaditi. ${ }^{7}$

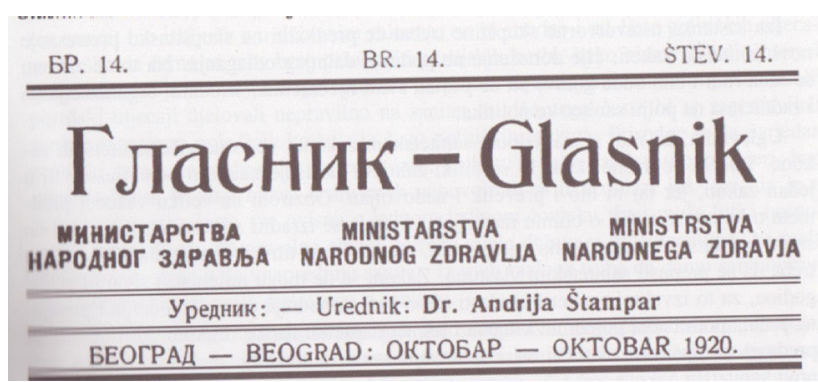

Slika 5. U Glasniku Ministarstva narodnog zdravlja, u kojem je bio urednik, Štampar je i sam često objavljivao, objašnjavajući zdravstvenu politiku koju provodi

6 Štampar, A. »O socijalnoj terapiii«. Glasnik Ministarstva narodnog zdravlja. 2(1919/20) 7, str. 261-271; Fatović-Ferenčić, S. »Društvo kao organizam i metafora kao polazište u Štamparovoj zdravstvenoj ideologiji«. U: I. Balen, L. Kovačić (ur.), Andrija Štampar, Radovi sa znanstvenih skupova Dani Andrije Štampara u Slavonskom Brodu. Posavska Hrvatska, Slavonski Brod 2009., str. 77-86.

7 Štampar, A. »O reformi medicinske nastave«. Glasnik Ministarstva narodnog zdravlja, 11(1920), str. 443-447. 
Nadalje, u istom izlaganju prigovara da se previše detaljno uči anatomija i histologija, dok se prilično zapostavlja biologiju. U kliničkom dijelu studija uči se samo praktična medicina, pritom se više teoretizira no prakticira pa je i sposobnost diplomiranih liječnika za provođenje kurativne medicine upitna. Nema spomena o socijalnom životu i patologiji, a u higijeni se ponešto govori o životu u gradu, ali baš ništa o higijeni sela. O nacionalnoj patologiji i njezinim specifičnostima nema govora. Prigovara i »maniji specijaliziranja« jer vodi brigu samo o karijeri liječnika, a ne o potrebama naroda. ${ }^{8}$

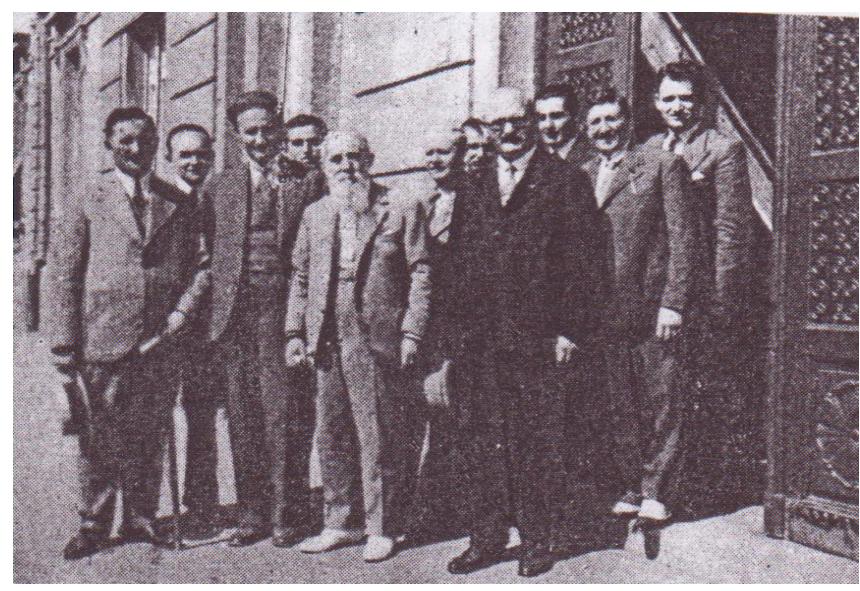

Slika 6. Štampar u Beogradu ranih 1920-ih kao načelnik Odjela za higijenu u Ministarstvu zdravlja. Desno od Štampara stoji Milan Jovanović-Batut, njegov prijatelj, učitelj i tadašnji ministar zdravlja.

Predlaže da se na prvim godinama studija više pažnje posveti biologiji, fizici i kemiji, kako bi se kasnije bolje razumjelo patologiju i farmakologiju. Posebnu pažnju treba posvetiti nacionalnoj patologiji, kao i svim epidemijama i endemijama koje se događaju u Jugoslaviji, kako bi liječnici mogli znati što ih čeka na terenu. Bez dobroga poznavanja te »patološke geografije« nema ni racionalnoga programa za suzbijanje pojedinih epidemija i endemija. Posebno se mora promijeniti nastava higijene jer to ne može na fakultetima biti nekakav nevažan sporedni predmet, s obzirom na vrlo nisku higijensku kulturu kod većega dijela naših naroda. Posebno se naši fakulteti moraju baviti higijenom sela, jer većina ljudi ipak živi na selu, a neki i u vrlo lošim higijenskim uvjetima. Na kraju misli da prije dozvole za rad liječnik mora obaviti dvije godine staža, te da u tom periodu treba odvojeno podučavati bolničke liječničke praktičare i liječnike za rad na terenu, napominjući da ih treba obučavati u općoj i socijalnoj higijeni, epidemiologiji, zdravstvenom zakonodavstvu, sudskoj medicini i 
bakteriologiji. Uvjeren je da radi toga studij treba trajati šest godina te da će na ovaj način školovani liječnici donijeti bolje dane narodnom zdravlju. ${ }^{9}$

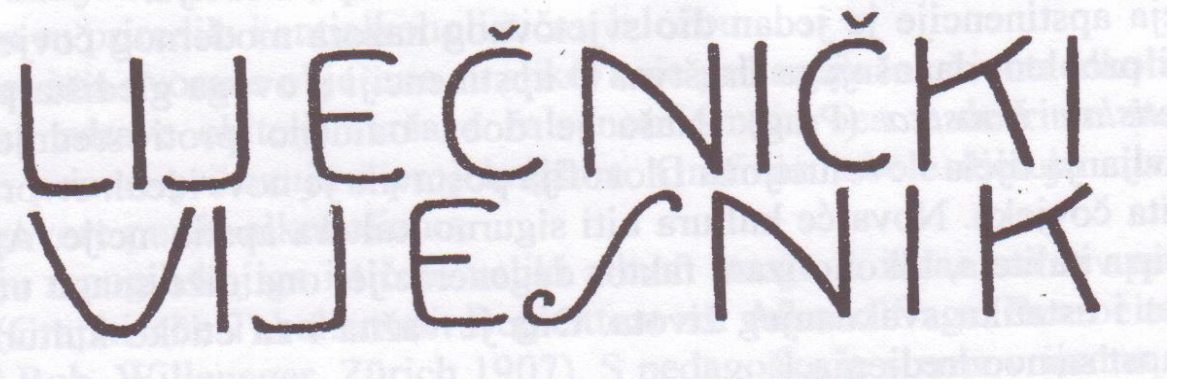

Slika 7. U Liječničkom vjesniku ponovno govori o nastavi na medicinskim fakultetima u Jugoslaviji kao dekan Medicinskoga fakulteta u Zagrebu 1941. godine.

Nakon dvadeset godina javlja se ponovno na temu nastave na fakultetima $\mathrm{u}$ Kraljevini Jugoslaviji, a isti je članak objavio i u sveučilišnom časopisu Alma Mater Croatica. Uvodno piše o malom broju liječnika u bivšoj Jugoslaviji, jer na jednoga liječnika dolazi oko 3500 stanovnika, dok većina razvijenih zemalja ima 3 do 4 puta veći broj liječnika. Još je veći problem u lošoj raspodjeli tih liječnika, s obzirom na to da je četvrtina liječnika u Beogradu i Zagrebu, gdje u to vrijeme živi oko 600000 ljudi, dok ostali dolaze na gotovo 15 milijuna stanovnika, što ima za posljedicu da u nekim banovinama jedan liječnik dolazi na 50000 do 65000 stanovnika, dok u Zetskoj banovini na jednoga liječnika dolazi čak 92000 stanovnika. Rezultat je da ima vrlo malo sela koja imaju liječnika pa se Štampar zalaže da se liječnike što više educira za rad na selu te da se liječnika koji prihvati službu na selu materijalno potpuno osigura. $U$ to je vrijeme već više od polovice liječnika završilo domaće fakultete, ali ni to nije povećalo broj liječnika na selu. Žali što današnja nastava na našim domaćim fakultetima priprema liječnika za rad u dobro uređenim ustanovama, najviše zato što su nastava higijene i socijalne medicine zapostavljene i zauzimaju »najnevidnije mjesto«. $U$ to vrijeme pred Drugi svjetski rat na beogradskom Medicinskom fakultetu studiralo je oko 1600 studenata, a na zagrebačkom oko 1000. Zagrebački je fakultet primao 320 studenata na prvu godinu, a beogradski 640. Štampar žali što je taj broj malen jer su svi drugi studiji (pravo, ekonomija, agronomija, bogoslovija) između dvaju svjetskih ratova rasli puno brže u broju studenata od medicine. Iako u većini zapadnih razvijenijih zemalja studij medicine traje šest do sedam godina, u Kraljevini Jugoslaviji cijelo je vrijeme studij trajao pet godina, odnosno deset semestara. Većina studenata studirala je duže, a kada se tome doda i godina obveznoga staža, ispada da studij traje jako dugo.

9 Ibid. 
Prema iskustvima drugih zemalja, ali i potrebama naroda, predlaže se: »/.../ studij se po predmetima i ispitima dijeli na tri grupe: 1 . Na opću i pripremnu grupu, 2. Na pretkliničku grupu, u kojoj će se medicinar upoznati s patološko-anatomskim i patološko-histološkim promjenama i patološko-fiziološkim pojavama te s općom etiologijom, dijagnostikom i terapijom bolesti i 3. Na kliničku grupu, u kojoj će po izvjesnom redu teoretski i praktički proučavati dijagnostiku i terapiju pojedinih grupa bolest/.../Slušači ne će moći početi upisivati i studirati predmete više grupe, dok ne polože sve ispite prethodne niže grupe./../U nastavi se mnogo veća pažnja posvećuje preventivnoj, konstruktivnoj i socijalnoj medicini /.../Uvode se praktične vježbe za vrijeme školskih praznika/.../ Slušači će radeći u vanjskim ustanovama upoznati zdravstvene prilike i pitanja u krajevima, u kojima će kasnije djelovati kao liječnici. $/ . . / \ll^{10}$

Poslije Drugoga svjetskog rata Svjetska zdravstvena organizacija uložila je velike napore da ujednači i poboljša kriterije izobrazbe liječnika. Od 1953. godine i kongresa u Londonu, na kojem je Štampar bio službeni delegat Svjetske zdravstvene organizacije, na kojem je bilo više od sto svjetskih medicinskih fakulteta, ti su kriteriji dogovoreni i način studiranja se širom svijeta ujednačuje. Naravno da se zadržava pravo pojedinim zemljama da uvažavaju svoje specifičnosti, a još jednom se naglašava važnost u edukaciji studenata iz područja preventivne medicine, osobito higijene i socijalne medicine. Uz to se preporučuje što više praktične nastave u kliničkim predmetima te produženje trajanja fakulteta na šest godina. Zahvaljujući tim prijedlozima i u bivšoj Jugoslaviji studij je bio produžen na šest godina, ali samo kroz desetak godina, jer je od 1962. godine ponovno uveden petogodišnji studij. Štampar je posebno bio zadovoljan što je Škola narodnog zdravlja od 1947. godine postala nastavna baza Medicinskoga fakulteta pa su ključni preventivni predmeti sada uče u okvirima škole. U zadnjim godinama svoga života uložio je i puno truda u osnivanje Više škole za medicinske sestre u okviru Medicinskoga fakulteta. Uspješno je proveo i svoja nastojanja oko osnivanja Medicinskoga fakulteta u Rijeci 1956. godine. ${ }^{11}$

\section{Obrazovanje liječnika}

Štampar se zalaže za trajnu edukaciju liječnika. Skupljajući iskustva po svijetu, zalaže se da se preventivnom medicinom, osim specijalista, bave i liječnici praktične medicine (liječnici opće medicine, odnosno danas obiteljske medicine). Svjestan je toga da

10 Štampar, A. »O reformi medicinske nastave«. Liječnički vjesnik, 63(1941) 1, str. 28-33.

11 Štampar, A. »Škola narodnog zdravlja i njezina uloga u unapređenju narodnog zdravlja«. Zdravstvene novine, 4(1951) 1, str. 3-4; Štampar, A. »Obrazovanje liječnika u našem društvu«. Vjesnik, 17(1956) 3473, 3500, 3501, str. 2; Štampar, A. »Nakon pet godina. Iskustva i problemi na Medicinskom fakultetu«. Zdravstvene novine, 10(1957) 9, str. 139-143. 
je za to potrebno educirati sve liječnike, najbolje kroz tečajeve koji traju po nekoliko dana jer takvi liječnici nisu u stanju duže odlaziti sa svojih radnih mjesta. Takvi se tečajevi mogu održavati samo u Školi narodnog zdravlja, a poželjno je s tim u vezi izdavati brošure o uputama (npr. o vakcinaciji). U poslovima prevencije liječnike treba upućivati na suradnju s veterinarima, agronomima i sanitarnim inspektorima. ${ }^{12}$

\section{Zaključak}

Štampar u svojem vremenu djeluje svježe i moderno u odnosu na edukaciju svih zdravstvenih kadrova, ali i reforme srednjoškolskoga odgoja. Veliki je trud ulagao u unaprjeđenje studija medicine, najviše u nastojanju da se dobiju dodatna znanja iz higijene i socijalne medicine. Zahvaljujući njegovu radu u fakultetskoj nastavi uvode se novi predmeti poput Uvoda u medicinu, Povijesti medicine i Medicinske statistike. Započinje i visoku edukaciju medicinskih sestara te osniva dvogodišnju školu za bolničare. Kao dekan Medicinskoga fakulteta u Zagrebu odigrao je vrlo važnu ulogu u osnivanju Medicinskoga fakulteta u Rijeci, tada drugoga medicinskoga fakulteta u Hrvatskoj.

\section{LITERATURA}

Balen, I., Jandrić-Balen, M. »Štampar kao prosvjetitelj«. U: I. Balen, L. Kovačić (ur.), Andrija Štampar, Radovi sa znanstvenih skupova Dani Andrije Štampara u Slavonskom Brodu. Posavska Hrvatska, Slavonski Brod 2009., str. 9-21.

Fatović-Ferenčić, S. »Društvo kao organizam i metafora kao polazište u Štamparovoj zdravstvenoj ideologijiк. U: I. Balen, L. Kovačić (ur.), Andrija Štampar, Radovi sa znanstvenih skupova Dani Andrije Štampara u Slavonskom Brodu. Posavska Hrvatska, Slavonski Brod 2009., str. 77-86.

Grmek, M. D. »Životni put Andrije Štampara, borca za unapređenje narodnog zdravlja«. U: Izabrani članci Andrije Štampara. Izdavački zavod Jugoslavenske akademije, Zagreb 1965., str. 13-49.

Štampar, A. »Iz područja socijalne medicine: Rad oko dizanja narodnog zdravlja«. Zvono, 3(1909) 24, str. $645-650$.

Štampar, A. »Iz područja socijalne medicine: Školski liječnik«. Zvono, 3(1909) 26, str. 710-713.

Štampar, A. »Seksualna pedagogika kao sredstvo u borbi protiv spolnih bolesti«. Jugoslavenska njiva, 3(1929) 14, str. 222-227.

Štampar, A. »Primjedbe k osnovu zakona o čuvanju narodnog zdravlja. Preventivni dio zakona«. Liječnički vjesnik, 41(1919) 8, str. 424-429.

Štampar, A. »Ideali života«, Hrvatski djak, 4(1909) 1, str. 10-11.

Štampar, A. »O socijalnoj terapiii«. Glasnik Ministarstva narodnog zdravlja, 2(1919/20) 7, str. 261-271.

Štampar, A. »O reformi medicinske nastave«. Glasnik Ministarstva narodnog zdravlja, 11(1920), str. 443-447.

12 Štampar, A. »Praktični liječnici preventivne i socijalne medicine«. Zdravstvene novine, 10(1957) 1, str. 3-5. 

studenata medicine i liječnika

Štampar, A. »O reformi medicinske nastave«. Liječnički vjesnik, 63(1941) 1, str. 28-33.

Štampar, A. »Škola narodnog zdravlja i njezina uloga u unapređenju narodnog zdravlja«. Zdravstvene novine, 4(1951) 1, str. 3-4.

Štampar, A. »Obrazovanje liječnika u našem društvu«. Vjesnik, 17(1956) 3473, 3500, 3501, str. 2.

Štampar, A. »Nakon pet godina. Iskustva i problemi na Medicinskom fakultetu«. Zdravstvene novine, 10(1957) 9, str. 139-143.

Štampar, A. »Praktični liječnici preventivne i socijalne medicine«. Zdravstvene novine, 10(1957) 1, str. 3-5.

Vukovac, S. »Hercules 20. stoljeća«. U: M. Bitunjac, T. Vlainić (ur.), Andrija Štampar, članci i rasprave, II. Sveučilište J. J. Strossmayera u Osijeku, sveučilišni udžbenik. Privlačica, Vinkovci 2008., str. 9-44.

\title{
ŠTAMPAR'S VIEWS ON THE HEALTH EDUCATION OF SCHOOL PUPILS, MEDICAL STUDENTS, AND PHYSICIANS
}

\author{
Marica Jandrić-Balen \\ Slavonski Brod \\ marica@jandric.com \\ Ivica Balen \\ Slavonski Brod \\ ivekbalen@gmail.com
}

\begin{abstract}
Public enlightenment and civic education were Štampar's obsessions since the beginnings of his career, but he also showed great interest in improving health education in schools as well as in teaching at faculties of medicine and providing long-term education of graduate physicians. He was first recommended for professorship as early as 1922, but it was only after the founding of the Banovina (Banate) of Croatia that he was granted a license for working at the Faculty of Medicine in Zagreb. He was 51 at the time. Soon afterwards, in 1940, he became Dean of the Faculty of Medicine in Zagreb but, unfortunately, World War II interrupted his career. He was interned in Austria during the war and, after its end, continued working as a university professor and director of the School of Public Health. In 1947, he became involved in undergraduate and postgraduate studies at the School of Public Health. From 1952 until his death in summer 1958, he was elected five times in a row as Dean of the Faculty of Medicine in Zagreb. During that time, he founded the second faculty of medicine in Croatia, in Rijeka in 1956. He also opened a college for nurses within the frame of the Faculty of Medicine in the mid-1950s, and introduced a two-year school for nurses, which they attended after completing elementary education. Thus, A. Štampar was effectively involved in faculty teaching for only 15 years, mainly towards the end of his life: two years before World War II and 13 years after it. Nevertheless, his work left a deep trace, above all in the form of constant efforts to affirm preventive medicine, hygiene, and social medicine.
\end{abstract}

Keywords: Andrija Štampar; health education; Faculty of Medicine 